African Crop Science Journal by African Crop Science Society is licensed under a Creative Commons Attribution 3.0 Uganda License. Based on a work at www.ajol.info/ and www.bioline.org.br/cs

DOI: https://dx.doi.org/10.4314/acsj.v28i1.12S

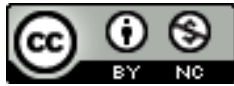

\title{
FACTORS INFLUENCING AGRIPRENEURS' INVESTMENT DECISION AND LEVEL IN CLEAN SEED POTATO ENTERPRISES IN THE HIGHLANDS OF KENYA
}

\author{
R.M. MUTINDA, E.W. GATHUNGU, A.M. KIBE ${ }^{1}$ and D.K. WAMBUA \\ Egerton University, Faculty of agriculture, Department of Agricultural Economics and \\ Agribusiness Management, P. O. Box 536-20115, Egerton, Nakuru, Kenya \\ ${ }^{1}$ Egerton University, Faculty of Agriculture, Department of Crop Horticultural and Soil, \\ P.O. Box 536-20115, Egerton, Nakuru, Kenya \\ Corresponding author: reddzmutinda@gmail.com
}

\begin{abstract}
High quality seed potato (Solanum tuberosum L.) supply has failed to meet the growing demand estimated at 250,000 metric tonnes from 161,000 ha of ware potato for cultivation by $600,000-800,000$ small-scale farmers in Kenya. Increased investments by private seed potato multipliers could alleviate the shortage of seed potato by enhancing availability and accessibility to quality seed, and bridging the supply that currently meets less than $5 \%$ of the demand. The objective of this study was to investigate factors that influence agripreneurs' investment decisions and level of investment in clean seed potato enterprise in the highlands of the Rift Valley, Kenya. The study was conducted through a cross-sectional survey of 380 agripreneurs. The Double hurdle (Craggit) model analysis revealed that training, frequency of extension services, family history in seed potato business, years spent in school and selling price, significantly $(\mathrm{P}<.05)$ influenced the probability of agripreneurs' decision to invest in clean seed potato enterprises in the highlands of Kenya. Initial land size put under seed potato production at the commencement of the enterprise, higher annual household income, number of cropping seasons, total land under seed potato and group membership fee also significantly ( $\mathrm{P}$ $<.05)$ influenced the decision and level of investment in clean seed potato enterprise.
\end{abstract}

Key Words: Double-hurdle, seed potato, Solanum tuberosum

\section{RÉSUMÉ}

L'offre de pommes de terre de semence de haute qualité (Solanum tuberosum L.) n'a pas répondu à la demande croissante estimée à 250,000 tonnes métriques de 161,000 ha de pommes de terre à vendre cultivé par 600,000 à 800,000 petits agriculteurs au Kenya. Des investissements accrus par des acteurs privés de pommes de terre de semence pourraient atténuer la pénurie de pommes de terre de semence en améliorant la disponibilité et l'accessibilité à des semences de qualité et en comblant le déficit d'approvisionnement qui répond actuellement à moins de $5 \%$ de la demande. L'objectif de cette étude était d'étudier les facteurs qui influencent la décision d'investissement des agro-entrepreneurs et le 
niveau d'investissement dans l'entreprise de pommes de terre de semence propres dans les hautes terres de la Rift Valley, au Kenya. L'étude a été réalisée grâce à une enquête transversale auprès de 380 agripreneurs. L'analyse du modèle à double obstacle (Craggit) a révélé que les formations, la fréquence des services de vulgarisation, les antécédents familiaux dans les entreprises de pommes de terre de semence, les années passées à l'école et le prix de vente augmentaient la probabilité que les agripreneurs décident d'investir dans des pommes de terre de semence propres de manière significative $(\mathrm{P}<0,05)$ dans les hautes terres du Kenya. La taille initiale des terres mises en production de pommes de terre de semence au début de l'entreprise, le revenu annuel des ménages plus élevé, le nombre de saisons de culture, la fréquence du service de vulgarisation, la superficie totale des terres de pommes de terre de semence et les frais d'adhésion au groupe ont également considérablement influencé la décision ( $\mathrm{P}$ $<0,05)$ et le niveau d'investissement dans une entreprise de pommes de terre de semence propre.

Mots Clés: Double obstacle, pomme de terre de semence, Solanum tuberosum

\section{INTRODUCTION}

Potato (Solanum tuberosum L.) is the second most produced and consumed food crop in Kenya, after maize (Zea mays L.). It also provides employment to millions of people, who participate in its entire value chain (KIPPRA, 2018). In Kenya, the seed regulating and certifying body, the Kenya Plant Health Inspectorate Services (KEPHIS), patronises seed potato quality right from breeding stage up to marketing. Two main seed potato systems are operational in the country, namely, the formal sector that is legally recognised by KEPHIS; and the informal sector that is not recognised as tradable seed. Unfortunately, the latter is dominant, accounting for over $97.4 \%$ of all seed produced in Kenya (Kaguongo et al., 2008; NPCK, 2017). There are three sub-systems within the informal seed potato production system; namely, clean seed (CS), positively selected seed (PSS) and farmsaved seed (FSS) potato.

Clean seed potato, which is not recognised by KEPHIS as certified seed, is considered as seed produced by non-registered farmers, who follow most, if not all of the regulatory processes without the monitoring and final certification by KEPHIS. Positively selected seed (PSS), on the other hand, is the seed produced through on-farm purposive selection of potato types possessing preferred phenotypic and genotypic traits. Farmer
Saved Seeds (FSS) is one that has been grown, selected for preferred traits and stored for planting in the next season by the famer (CIP, 2011). Local farmers, with minimal local government and international research contribution, have largely driven the potato industry in Kenya.

Support of clean seed potato production can increase potato productivity and enhance access, as long as good agricultural practices are adhered to. Clean seed has been found to be more productive than farm-saved seed potato (Kaguongo et al., 2013). Gildemacher et al. (2011) also reported that $95 \%$ of seed potato in Ethiopia, Kenya and Uganda was produced by local seed systems considered as unofficial. Gildemacher et al. (2011) recommended a different outlook on seed potato production, whereby ware potato producers should also get involved in the production of high quality seed potato. This decentralised network of clean seed producers was also recommended in Kenya by the Internatinal Potato Centre (CIP) in 2011 in order to improve availability of quality seed potato locally. Such farmer based clean seed, refered to as quality declared seed in Ethiopia, has also been reported to increase seed supply as well as improve seed markets in Ethiopia (Walelign, 2008).

Despite the benefits of using clean seed potato outlined above, and the potential to be adopted by more regional and local seed 
producers, its production capacity is still low. This creates a large gap between the supply of high quality seed potato and demand by the small scale ware potato producers, although the number of agripreneurs investing in clean seed potato is still low. The objective of this study was to investigate factors that influence agripreneurs' investment decision and level of investment in clean seed potato enterprise in the highlands of Rift valley, Kenya.

\section{METHODOLOGY}

This study was conducted in Nakuru County, purposively selected from 13 potato-growing counties, because of its substantial area under potato production in Kenya. Nakuru is located at longitude $35^{\circ} 24^{\prime} 36^{\prime \prime}$ and $36^{\circ} 36^{\prime} 0^{\prime \prime}$ E and latitude $0^{\circ} 13$ ' $48^{\prime \prime} \mathrm{N}$ and $1^{\circ} 9^{\prime} 36^{\prime \prime} \mathrm{S}$, in the central Rift Valley in Kenya (Nakuru County Government, 2018). Molo sub-county was also purposively selected with all its administrative wards; namely, Molo, Turi, Marioshoni and Elburgon, being the leading seed potato producers in Nakuru County.

A sample of 380 potato agripreneurs, that is farmers who grow and market both ware and seed potato, was considered for the study. The sample size was calculated using the probability proportionate to size methodology specified by Israel (1992) (Equation1):

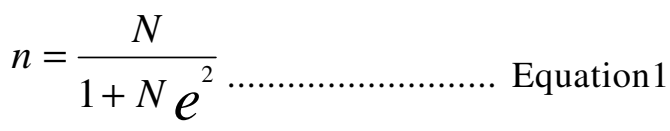

Where:

$\mathrm{n}=$ the sample size, $\mathrm{N}=$ the total population, and $=$ is the precision error.

The total population of agripreneurs in Molo Sub-County was 7,731, distributed in the wards of Molo (2586), Marioshoni (1053), Turi (1527) and Elburgon (2565) (Molo SubCounty Agricultural Officer, 2019 personal communication).
The household heads were the respondents and were interviewed on a face-to-face basis, using a semi-structured questionnaire. The questionnaire was pretested to 30 agripreneurs and improved for easy data collection.

The empirical model of investment, Double Huddle (Craggit) used consisted of two-stages; namely whether or not to participate (uptake of a particular investment); and if the decision was to participate then how much invested in the enterprise (level). The dependent variables contained zeros for the agripreneurs who did not invest in clean seed potato, and a certain amount of investment for who invested in the enterprises.

The positive observations on investments could be collapsed and treated as binomial probit estimates, but that would loose all the information on the amount invested in the seed enterprises. Likewise, zero observations could be discarded, but it would lead to truncated distribution weaknesses. An important consideration in quantifying investment decisions was assumed to be the existence of a large number of zero observations in the data set. Excluding agripreneurs with zero seed investment from the sample would lead to a selection bias.

It was, therefore, important to include zero, as well as non-zero observations in the estimation model. Tobit model is frequently used for dealing with zero observations and discrete weaknesses (Tobin, 1958). The model employs maximum likelihood and combines probit, as well as regression components of log-likelihood function (Baum, 2006). The weakness with Tobit model is its restrictiveness, in that any variable that increases the probability of a non-limit value must also increase the mean of the positive value, which is not always reasonable (Lin and Schmidt, 1984).

Heckman's two-stage model is an alternative for the Tobit model; it allows one set of parameters to determine the probability of a limit observation (decision to invest or not), and a second set of parameters to 
determine the probability of the non-limit observation (level of seed potato investment). However, Heckman is appropriate when there is censoring process in estimating the extent of investment (Heckman, 1976). In this study, the zeros in extent of investment were not due to investing in seed potato enterprise, hence was neither due to corner solution nor sample selection.

In this study, the appropriate model was Double-Hurdle model (Craggit). It assumes that agripreneurs are faced with two hurdles in any agricultural decision making process (Cragg, 1971). The two-step model allows different mechanisms to determine the discrete probability of participating in seed potato enterprises and the level of investment. It is assumed that some independent variables may affect differently the decision to participate in seed potato at all and the decision on the level of investment. The Double Hurdle model approach, and specifically Craggit model, has been widely considered in studies on participation or uptake of agricultural technologies and the level of commercialisation after uptake (Mignouna et al., 2015; Wang et al., 2016; Hsueh and Kasperski, 2018; Burke, 2019).

The first stage involved running a probit regression for identification of factors influencing the decision to invest in clean seed potato enterprise. The dependent variable was whether an agripreneur invested in clean seed enterprise coded as one (1), or did not coded as zero (0) in the first tier. The independent variables used to explain clean seed potato enterprise included years in seed potato, sex of agripreneurs, age, years spent in school, selling price, number of times they received extension services, group membership and family history in seed business.

The average amount of money invested for five potato seasons was used as the measure of level of investment in clean seed potato. This was to reduce bias that would be as a result of high or low investment for one season. The explanatory variables for the second tire were years in potato farming, number of seasons one produced, total land under seed, soil testing cost, annual income, marketing cost, credit acquisition, times got extension service, cost of building seed store, acres started producing and group membership fee. STATA version 13 software was used to process the quantitative data.

\section{RESULTS AND DISCUSSION}

Decision to invest. The results of the first tier depicted that sex, age, years spent in school, household members, access to seed store, years in potato farming, seed selling price, attending trainings and extension services frequency of respondents, significantly influenced decision to invest in seed potato enterprises (Table 1).

Being male increased the probability of investing in clean seed potato enterprises by $36 \%$. This was so probably because male agripreneurs have better networks in society which place them in better positions to get more information and new production techniques compared to females (Mudege $e t$ al. 2015). This result is consistent with findings from a study by Mudege et al. (2015) in Malawi, which found out that, although both men and women were involved in ware and seed potato production, men were focused in seed potato production and marketing. Mulate et al. (2018) in Ethiopia also found out that women played limited roles in local seed production activities, because their position in leadership and decision-making was not appreciated. This implies that targeting extension and training services on seed potato production techniques, to female agripreneurs has the potential to encourage them invest in clean seed potato enterprise. This could lead to more men and women investing in seed potato, hence, increased supply of high quality seed.

The number of years the agripreneurs spent in school positively influenced $(\mathrm{P}<0.05)$ their decision to invest in clean seed potato enterprises by $29 \%$ (Table 1). A unit increase in time spent in school increased the probability 
TABLE 1. Tier-1-factors influencing growing of clean seed potato as an enterprise in the highlands of the Rift Valley, Kenya

\begin{tabular}{lcccc}
\hline Variable & Coefficient & Standard Error & $\mathrm{Z}$ & $\mathrm{P}>\mathrm{Z}$ \\
\hline Sex of respondent & 0.360 & 0.967 & 1.41 & $0.160^{*}$ \\
Ward of residence & 0.258 & 0.233 & 1.110 & 0.267 \\
Age of respondent (years) & 0.064 & 0.042 & 1.520 & $0.128^{*}$ \\
Years spent in school & 0.290 & 0.113 & 2.560 & $0.010^{* *}$ \\
Household members & -0.240 & 0.133 & -1.800 & $0.072^{*}$ \\
Main source of income & 0.146 & 2.202 & 0.520 & 0.603 \\
Access to seed store & 0.884 & 0.646 & 1.370 & $0.171^{*}$ \\
History of seed business in family & 0.625 & 0.730 & 2.220 & $0.026^{* *}$ \\
Years in potato farming & 0.064 & 0.046 & 1.390 & $0.166^{*}$ \\
Seed selling price per 50 kg bag & 0.182 & 0.001 & 3.710 & $0.000^{* * *}$ \\
Acquired credit & 0.550 & 0.597 & 0.920 & 0.357 \\
Attended training & 0.724 & 0.905 & 2.140 & $0.032^{* *}$ \\
Times got extension service & 0.724 & 0.279 & 2.590 & $0.010^{* *}$ \\
Group membership & 0.182 & 0.624 & 0.290 & 0.770 \\
Logged annual income & -0.270 & 0.305 & 1.060 & 0.288 \\
Total land under seed & 0.972 & 0.463 & -0.890 & 0.376 \\
Constant & -9.643 & 4.930 & -1.960 & 0.050 \\
& & & & \\
Number of observations $=380$ & & & & \\
Wald Chi ${ }^{2}=29.61$ & & & & \\
Prob>Chi ${ }^{2}=0.020$ & & & & \\
Log likelihood=-67.758 & & & &
\end{tabular}

* Significant at $10 \%(*), 5 \%(* *)$ and $1 \%(* * *)$ probability levels

of investing in clean seed potato enterprise by $30 \%$. This can be attributed to the fact that education equips agripreneurs with information and knowledge to make informed decisions related to seed potato.Therefore, stakeholders in potato sector should focus on encouraging people with relatively low education level to take up clean potato seed enterprise. Capacity building through targeted extension services can be used to enhance the skills of interested agripreneurs who may not have high levels of formal education. This can also target young people who are unemployed and encourage them to take up the venture. Our finding is similar to those of Sebatta et al. (2014) in Uganda, who noted that secondary schooled level farmers were more likely to be involved more in potato production and marketing.
A unit increase in age of agripreneurs' by one year increased the probability of investing in clean seed potato enterprises by $6.4 \%$, although at a higher significance level $(\mathrm{P}<0.1)$ (Table 1). To invest in seed potato enterprise, one requires experience in production, as well as marketing. Relatively older agripreneures have more experience in crop production and are more resource endowed compared to younger ones (Akudugu et al., 2012).

These results are consistent with a study done by Nwibo and Alimba (2013), in which age had a positive influence on determinants of investment decision among agribusiness investors in South East, Nigeria. They attributed this to the fact that relatively older investors above 60 years have high efficiency 
in production and they can handle difficulties that can arise from farm related enterprises.

However, our results contrasted with those of Demisse (2010) in Ethiopia, where an increase in age by one year was found to have a negative influence on smallholders being involved in local based seed system. Hagos et al. (2018) also recently found out that an increase in age of smallholder farmers' involvement in seed production, Ethiopia negatively influenced their decision.

The number of people living with and depending on the agripreneurs, negatively influenced $(\mathrm{P}<0.1)$ the decision to invest in seed potato enterprises by $24 \%$ (Table 1 ). A unit increase in the number of the people in a household decreased the probability of investing in clean seed potato enterprises by $24 \%$. This could be because large population sizes need more food, hence, agripreneurs with large families may give priority to ware potato production, hence, reduced investments in seed potato enterprises. This means that sole agripreneurs have more potential of investing in seed potato enterprises; they should be more supported to increase high quality seed potato supply. These findings contrast with those of Hagos et al.(2018), who found out that large family size positively influenced decision to be involved in seed production. This was explained to be caused by the fact that large family size provided labour, hence, easy to manage seed production activities properly.

Agripreneurs with previous experience in seed business had greater probability $(\mathrm{P}<0.05)$ of making the decision to invest in clean seed potato enterprises than their counterparts by $62.5 \%$ (Table 1). This is an indication that agripreneurs who are already in seed potato business should be supported to expand their seed production capacity. This is because they have learnt through experience and it would be easier to build on their successes, while correcting their mistakes in seed enterprise. These results are consistent with those of Nwibo and Alimba (2013), who found out that household history influenced decisions to invest in agriculture related enterprises. People tend to adopt what they have seen others doing in the past or something they are aware of from acquiring information (Hagos et al., 2018). Therefore, agripreneurs who had previous experience in seed potato or any other seed business had a higher probability of investing in clean seed potato enterprises.

Experience in potato farming influences $(\mathrm{P}<0.1)$ the decision to invest in seed potato enterprise by $6.4 \%$ (Table 1). An increase in experience of the agripreneur by one year increased the probability of investing in seed potato enterprise. This means that agripreneurs with more experience in potato farming have higher ability to invest in seed potato enterprises than those with less experience, because, they have more knowledge and skills. This implies that stakeholders seeking to expand potato production can mostly focus on agripreneurs with experience in potato farming, as they will easily diversify their potato enterprises and adopt seed potato enterprise. Our finding is supported by the findings of Bukul (2018) that an increase in farmers experience by one year, increases the probability of producing potatoes. They attributed this to; farmers with experience in potato production to produce more because of extra acquired skills and information.

A selling price of a $50 \mathrm{~kg}$ bag of seed potato had an influence $(\mathrm{P}<.01)$ on the decision to invest in clean seed potato enterprises by $18.2 \%$ (Table 1). Agripreneurs responded to relatively good prices because this translated into increased incomes. The agripreneurs reported selling approximately $50 \mathrm{~kg}$ bag of clean seed potato from US\$15-20, depending on seed demand. The producer's goal is to maximise profit and this can be achieved through cost reduction or increased revenue (Debertin, 2012). Selling price, therefore, plays an important role in increasing revenues and encouraging investment in seed potato production. To encourage higher uptake of the ventures among potential agripreneurs, the marketing of seed potato should be regulated 
to avoid price exploitation of the producers that can discourage them from investing in seed potato enterprise

Our finding was in agreement with that of Akudugu et al. (2012), who reported that the decision to invest in any enterprise was affected by the benefits attained, as well as costs incurred. This was reported to be due to farmers' being likely to adopt agricultural production technology that gives more benefits.

Access to and attending trainings on potato farming positively influenced the decision to participate in seed potato enterprise $(\mathrm{P}<0.05)$ by $72.4 \%$ (Table 1 ). This may be because agripreneurs who attended trainings got in contact with extension officers and were always updated with new technologies, as well as production methods, than those who did not attend.

Our results are consistent with those of Yami et al. (2013) and Hagos et al.(2018), who reported that attending trainings positively influenced farmers decision to produceseed. They attributed this to; getting training equipped farmers with information, hence, improving seed production.

This implies that trainings are important to convince and provide knowledge on practicability of seed potato production. Therefore, research and training institutes that focus on improvement of potato production should also develop modules on seed potato production. Field days and farmer exposure trainings should also be encouraged as a mode of sharing knowledge with agripreneurs. This can be done in collaboration with existing government and non-governmental institutions offering extension services to potato farmers.

The number of times the agripreneurs got extension services positively influenced $(\mathrm{P}<0.05)$ the decision to invest in seed potato enterprise by $72.4 \%$ (Table1). This implies that agripreneurs who access extension services gain more knowledge, hence increase investment in seed potato business than those who get the services less times.
These results were similar to those of Yami et al. (2013) and Hagos et al. (2018), who underscored the role of extension services in bridging gaps that exist between agripreneurs practices and technical knowledge. It was, however clear that, extension personnel on the ground were insufficient to provide this essential service.

Extension services should be strengthened to increase the rate at which they disseminate knowledge on seed potato production. Agripreneurs on the other hand should be sensitised to participate in these learning opportunities.

Having access to a seed storage positively influenced $(\mathrm{P}<0.1)$ the decision to invest in clean seed potato enterprise by $88.4 \%$ (Table 1). Agripreneurs with access to seed potato storage had a relatively higher probability of investing in seed potato enterprise. Seed potato storage is crucial when one is in seed potato production. These results corroborated with those of Yami et al. (2013), who opined that access to inputs, positively and significantly influenced farmer's decision to participate in bread wheat seed and seed potato multiplication. The national government may, therefore, consider partnering with county governments and the private sector to build seed potato stores in potato growing regions. These stores can be made available to agripreneurs at an affordable fee for storage, so as to encourage agripreneurs to invest in seed potato, hence, increase high quality seed potato supply in the country.

Level of investment in seed potato enterprises. The initial land size to be put under seed potato production by the agripreneurs, had a positive influence $(\mathrm{P}<0.01)$ on the level of investment in clean seed potato enterpriseby $51 \%$ (Table 2). If the initial land size increased by 0.41 ha from one agripreneur to another, the amount invested increased by $51 \%$. This could be because the more the land under clean seed potato, the more the production costs incurred, including 
TABLE 2. Tier-2- factors influencing levels of investment in clean seed potato enterprises in the highlands of Rift valley, Kenya

\begin{tabular}{lcccc}
\hline Variable & Coefficient & Standard Error & $\mathrm{Z}$ & $\mathrm{P}>\mathrm{Z}$ \\
\hline Number of seasons produced & 0.216 & 0.054 & 4.040 & $0.000^{* * *}$ \\
Total land under seed (ha) & -0.123 & 0.091 & -1.350 & $0.018^{* * *}$ \\
Total soil testing cost & 0.000 & 0.000 & 0.460 & 0.646 \\
Logged annual income & -0.464 & 0.141 & -3.280 & $0.001^{* * *}$ \\
Total marketing cost & 0.000 & 0.000 & -0.990 & 0.324 \\
Acquired credit & 0.216 & 0.170 & 1.270 & $0.000^{* * *}$ \\
Times got extension service & 0.185 & 0.049 & 3.810 & $0.000^{* * *}$ \\
Group registration fee & 0.120 & 0.010 & -1.030 & $0.034^{* *}$ \\
Logged training cost & 0.025 & 0.024 & 1.020 & 0.309 \\
Logged cost of building seed store & -0.002 & 0.015 & -0.150 & 0.877 \\
Acres started producing & 0.510 & 0.111 & 4.580 & $0.000^{* * *}$ \\
Constant & 9.925 & 0.195 & 50.900 & 0.000 \\
Number of observations=380 & & & & \\
Wald Chi ${ }^{2}=29.61$ & & & & \\
Prob>Chi ${ }^{2}=0.020$ & & & & \\
Log likelihood=-67.758 & & & & \\
\hline
\end{tabular}

*Indicates significance at $10 \%(*), 5 \%(* *)$ and $1 \%(* * *)$ probability levels

agricultural inputs (seed, labour, pesticide, fungicide and fertilisers) costs. This result is in line with finding of Bukul (2018) who reported that an additional land allocated for potato production increased amount of money invested.

Acquistion of credit significantly and positively influenced $(\mathrm{P}<0.01)$ the amount invested in clean seed potato enterprise by $21.6 \%$ (Table 2). Access to credit enables agripreneurs to buy required inputs in seed potato enterprises; hence, it is reasonable that it leads to increased amount of money invested in seed potato production. This finding suported that of Manishimwe et al. (2019), who reported that acquring credit helps farmers to pay for agricultural services and inputs, hence, increases levels of production in Rwanda.

The frequency of getting extension service significantly and positively influenced $(\mathrm{P}<0.01)$ the amount of money invested in clean seed potato enterprise by $18.5 \%$ (Table 2). Increasing the number of times that an agripreneur got extension services by one unit, increased amount invested in seed potato by by $18.5 \%$. This can be atrributed to getting more exposure to modern potato production technologies, hence, increased production. CIP (2011) also noted that strong extension service system led to more investment in seed potato.

Increase in annual income had a negative feedback influence $(\mathrm{P}<0.01)$ on amount invested in clean seed potato enterprise (Table 2). This finding corresponds to that of Onoja and Emodi (2014) who reported a negative correlation between annual income and amount invested in agribusiness enterprise.

\section{CONCLUSION}

The results of this study suggest that strengthening training and extension services related to seed potato enterprise will help in attracting agripreneurs in seep potato ventures. Furthermore, access to better seed storage facility by agripreneurs will enable them to fetch better seed potato prices. 


\section{ACKNOWLEDGEMENT}

The authors are grateful to the Mastercard Foundation and Regional Universities Forum for Capacity Building in Agriculture (RUFORUM) for funding research and publication cost through the Transforming African Agricultural Universities to meaningfully contribute to Africa's growth and development (TAGDev) Program.

\section{REFERENCES}

Akudugu, M. A., Kwesi, S. and Dadzie, N. 2012. Adoption of modern agricultural production technologies by farm households in Ghana: What factors influence their decisions? Journal of Biology, Agriculture and Healthcare 2(3):1-15.

Baum, C. F. 2006. Limited dependent variables: An introduction to modern econometrics using stata. Birmingham: STATA press. Retrieved January 10, 2019, from www.birmingham.ac.uk.

Bukul, B.B. 2018. Factors affecting smallholder farmers potato production in Shashemene district, West Arsi Zone, Oromia National Regional. Food Science and Quality Management 76(1):66-72.

Burke, W. J. 2019. Evidence against imposing restrictions on Hurdle Models as a test for simultaneous versus sequential decision making. American Journal of Agricultural Economics 101(5):1473-1481.

Cragg, J. 1971. Some statistical models for limited dependent variables with application to the demand for durable goods. Econometrica 39(5):829-844.

Debertin, D. 2012. Agricultural production economics, Uknowledge, University of Kentucky, Lexington, Kentucky, USA. $61 \mathrm{pp}$.

Demisse, F. 2010. Determinants of smallholders' participation in local based seed production system: The case of onion seed in East Shoa Zone of the Oromiya
National Regional State, Ethiopia. M.Sc. Thesis, Haramaya University, Ethiopia. $84 \mathrm{pp}$.

Gildemacher, P.R., Schulte-Geldermann, E., Borus, D., Demo, P., Kinyae, P., Mundia, P. and Struik, P.C. 2011. Seed potato quality improvement through positive selection by smallholder farmers in Kenya. Potato Research 54(3):253-266. doi: 10.1007/ s11540-011-9190-5.

Hagos, K., Tesfaye, L. and Girmay, T. 2018. Determinants of smallholder farmers participation in seed producing cooperatives in Southern Zone of Tigray, Ethiopia. Journal of Agricultural Extension and Rural Development 10(4):75-83. doi: 10.5897/jaerd2017.0868.

Heckman, J.J. 1976. Sample selection bias as a specification error. Econometrica: Journal of Econometric Society 153-161.

Hsueh, L. and Kasperski, S. 2018. The impact of catch shares on multiregional fishery participation and effort: The case of West Coast harvesters in the Alaska Fisheries. Marine Policy 95:123-132.

International Potato Center (CIP). 2011. Roadmap for investment in the seed potato value chain in Eastern Africa. Lima, Peru, $27 \mathrm{pp}$.

Israel, G.D. 1992. Determining sample size, Agricultural Education and Communication Department, University of Florida, IFAS extension, PEOD6.

Kaguongo, W., Gildemacher, P., Demo, P., Wagoire, W., Kinyae, P.,Andrade, J., Forbes, G., Fuglie, K. and Thiele, G. 2008. Farmer practices and adoption of improved potato varieties in Kenya and Uganda. Social Sciences Working Paper 5(85):6768.

Kaguongo, W., Maingi, G., Barker, I., Nganga, N. and Guenthner, J. 2013. The value of seed potatoes from four systems in Kenya. American Journal of Potato Research 91(1):109-118. doi: 10.1007/s12230-0139342-z. 
Kenya Institute for Public Policy Research and Analysis (KIPPRA). 2018. Supporting sustainable development through research and capacity building. Discussion Paper (9):1-28.

Kenya Plant Health Inspectorate Services (KEPHIS). 2016. Seed Potato Production Certification Guidelines Handbook. 45pp.

Lin, T.F. and Schmidt, P. 1984. A test of the Tobit specification against an alternative suggested by cragg. The Review of Economics and Statistics 174-177.

Manishimwe, R., Niyitanga, F., Nsabimana, S., Kabayiza, A. and Mutimawurogo, M. C. 2019. Socio-economic and institutional factors influencing the potato (Solanum tuberosumL.) production at smallholder farmers level in the Gicumbi district in Rwanda. Journal of Tropicultura 37(2):110.

Mignouna, D.B., Abdoulaye, T., Alene, A., Akinola, A.A. and Manyong, V.M. 2015. Drivers of market participation decisions among small-scale farmers in yam growing areas of Nigeria and Ghana (No. 10082016-80294).

Mudege, N. N., Kapalasa, E., Chevo, T., Nyekanyeka, T. and Ndemo, P. 2015. Gender norms and the marketing of seeds and ware potatoes in Malawi. Journal of Gender, Agriculture and Food Security 1(2): 18-41.

Mulate, B., Eyayu, B. and Jameel, M. 2018. The role of women headed households in the local seed business in Ethiopia: The case of Jabi Tehnan, Bure and Yilmana Densa districts. Global Journal of HumanScience- $a$ Arts and Humanities-Psychology 18(3):23-33.

Nakuru County Government. 2018. County Government of Nakuru Nakuru County Integrated. Development Plan (2018-2022). Ministry of Planning, Kenya.
National Potato Council of Kenya (NPCK). 2017. Potato Variety Catalogue, 2017 Handbook. 20pp.

Nwibo, U.S. and Alimba, O.J. 2013. Determinants of investment decisions among agribusiness investors in South-East, Nigeria. IOSR Journal of Business and Management 8(6):60-67. doi: 10.9790/ 487x-0866067.

Onoja, A. and Emodi, A. 2014. Factors influencing agricultural business investment decision by women in rivers state, Nigeria. Production Agriculture and Technology (PAT)10(2):32-43.

Sebatta, C., Mugisha, J., Katungi,E., Kashaaru, A. and Kyomugisha, H. 2014. Smallholder farmers' decision and level of participation in the potato market in Uganda. Modern Economy 5(8):895-906. doi:10.4236/me.2014.58082.

Tobin, J. 1958. Estimation of relationships for limited dependent variables. Econometrica Journal of the Econometric Society: 2436.doi:10.2307/1907382.

Walelign, G. 2008. Determinants and role of farmers' seed and seedling multiplication in the SNNP region seed system. M.Sc. Thesis. Haramaya University, Ethiopia. 49pp.

Wang, P., Wolf, S. A., Lassoie, J. P., Poe, G. L., Morreale, S. J., Su, X. and Dong, S. 2016. Promise and reality of market-based environmental policy in China: Empirical analyses of the ecological restoration program on the Qinghai-Tibetan Plateau. Global Environmental Change 39:35-44.

Yami, M., Tesfaye,T. and Bekele, A. 2013. Determinants of farmers? Participation decision on local seed multiplication in Amhara Region,Ethiopia: A Double Hurdle Approach. International Journal of Science and Research (IJSR)2(1): 423430. Available at: https://www.ijsr.net/ archive/v2i1/IJSR13010172.pdf. 